$\begin{array}{lllllllllllllllll}\mathrm{S} & \mathrm{T} & \mathrm{U} & \mathrm{D} & \mathrm{I} & \mathrm{A} & \mathrm{I} & \mathrm{M} & \mathrm{A} & \mathrm{T} & \mathrm{E} & \mathrm{R} & \mathrm{I} & \mathrm{A} & \mathrm{L} & \mathrm{Y}\end{array}$

Cecylia Leszczyńska

ORCID: https://orcid.org/0000-0003-4919-7695

University of Warsaw, Faculty of Economic Sciences

email: cleszczynska@wne.uw.edu.pl

\title{
Polish Emigration Abroad: Regional Structure and Streams of Emigration in the Years 1870-1914 and 1918-1939
}

\section{Polska emigracja zagraniczna. Struktury regionalne i kierunki w latach 1870-1914 i 1918-1939}

\begin{abstract}
Emigration from the territory of Poland was a mass phenomenon at the end of the 19 th century. Its characteristic feature was that it was gainful emigration, and the predominant destination was the United States. The second most popular destination was West European countries (mainly Germany). Emigration to Russia took place on a smaller scale. In the interwar period, the rate of emigration decreased markedly. The directions also changed: the US became less popular, and emigration to France and Belgium gained in importance. Seasonal emigration (Germany, Latvia) was important from the economic and social points of view. This paper aims at analyzing the demographic dimension of both waves of emigration, and to
\end{abstract}

\begin{abstract}
Abstrakt
Emigracja z ziem polskich stała się zjawiskiem masowym w końcu XIX wieku. Jej charakterystyczną cechą był zarobkowy charakter oraz dominujący kierunek wyjazdów - Stany Zjednoczone AP. Na drugim miejscu były migracje do przemysłowych krajów europejskich (głównie do Niemiec). Mniejsze rozmiary miała emigracja do Rosji. W okresie międzywojennym emigracja uległa silnemu spadkowi, nastąpiła też zmiana kierunków: spadły wyjazdy do USA, ważne stały się wyjazdy do Francji i Belgii. Ważna ekonomicznie i społecznie była emigracja sezonowa (Niemcy, Łotwa). Celem opracowania jest oszacowanie skali i struktury emigracji na poziomie regionalnym w okresie 1870 1914 i 1918-1938 w celu określenia ubytku
\end{abstract}


estimate the scale and structure of emigration at regional level in 1870-1914 and 1918-1938 in order to determine net "loss" in population. The method was the analysis of census statistics from 1890-1931 at the regional level (for the late 1930s, estimates) and the analysis of emigration statistics.

\section{Keywords}

emigration from Polish territories, origin of emigrants, Poland in the 19th century, Second Polish Republic ludności. Metoda to analiza statystyk spisowych z lat 1890-1931 na poziomie regionalnym (dla końca lat 1930 - szacunki) oraz analiza statystyk emigracyjnych.

\section{Słowa kluczowe}

emigracje z ziem polskich, pochodzenie emigrantów, Polska w XIX wieku, Druga Rzeczpospolita

\section{Introduction}

Emigration from Polish territories grew in the second half of the 19th century in parallel with the global movement of people occurring in the majority of the countries of that time. Some of them, such as the US or South American countries, were primarily immigration countries; in turn, European countries were emigration countries. However, some of them (Germany) performed both "roles." Emigration processes were the result of many circumstances. They were determined by the economic, social and demographic situation of the sending country and the receiving country, the availability of means of transport (railways, maritime transport), migration policies, the activity of passenger transport companies and the scope of family connections networks facilitating so-called chain emigration. In the interwar period, the above-mentioned circumstances changed. First of all, the immigration policies of the most important countries (especially the US) were tightened and institutional control and surveillance of emigration in emigration countries were strengthened. Settlement-oriented emigration was significantly reduced, and temporary emigration, strongly dependent on the economic situation, also decreased. This was particularly negatively affected by the Great Depression in the 1930s.

This paper aims at a comparative analysis of emigration from Polish provinces in the following two periods: a) 1870-1914, when these provinces (the Kingdom of Poland, western governorates of the Russian Empire, Galicia and Prussian partition) belonged to three different states and three institutional and statistical systems (the Russian, Austrian and Prussian Empires); b) 1918-1938 when these 
provinces became groups of voivodeships in the Polish state (central, eastern, southern and western voivodeships). These groups of voivodeships roughly corresponded to the partitioning territories of 1870-1914. The number of emigrants in 1870-1914 is based on the research of other authors, the number of emigrants by voivodeship in 1918-1938 is based on the number of passports issued in the voivodeship. Unfortunately, it is not possible to analyze re-emigration by voivodeship (it was not registered in voivodeships).

This paper aims to analyze the demographic dimension of both waves of emigration and to estimate the scale and structure of emigration at regional level in 1870-1914 and 1918-1938. The basic research question concerns the problem of the regional intensity of emigration in the period 1870-1914 (when emigration processes took on a large scale) and the period 1918-1938, when there was a strong decline in emigration. The analysis in this paper may constitute a starting point for further research on the role of migration networks in Polish emigration in the long historical perspective. ${ }^{1}$ This phenomenon was already studied for the nineteenth century, ${ }^{2}$ but a comparative study of emigration in 1870-1914 and 1918-1939 has not yet been undertaken, especially in a regional system.

The main source for this paper is the migration statistics from the Warsaw Statistical Committee, the US Department of Labor Annual Reports and the Polish Central Statistical Office. Other sources are studies on Polish emigration. This subject has of course a vast literature of its own; emigration in the 19th century and in the period 1918-1939 were usually analyzed separately: the 19th century refers to the respective partitioning provinces or destination countries, ${ }^{3}$ while the period 1918-1938 refers to the respective destination countries, type of emigration

\footnotetext{
${ }^{1}$ Migration networks are recognized as one of the important determinants of emigration. Migration networks can be part of a wider approach called "cumulative causation." James T. Fawcett, "Networks, Linkages, and Migration Systems," International Migration Review 1989, no. 23, 671-680; Douglas Massey, "Social Structure, Household Strategies, and the Cumulative Causation of Migration," Population Index 1990, vol. 56, no. 1, 3-26; Ewa Morawska, "International migration: Its various mechanisms and different theories that try to explain it," Willy Brandt Series of Working Papers in International Migration and Ethnic Relations 2007, no. 1, 6-7.

${ }^{2}$ Dorota Praszałowicz, Krzysztof A. Makowski, and Andrzej A. Zięba, Mechanizmy zamorskich migracji lańcuchowych w XIX wieku: Polacy, Niemcy, Żydzi, Rusini: zarys problemu (Kraków: Księgarnia Akademicka, 2004); Ewa Morawska, "Labor Migration of Poles in the Atlantic Economy, 1880-1914," Comparative Studies in Society and History 1989, no. 3, 237-272.

${ }^{3}$ Krzysztof Groniowski, Polska emigracja zarobkowa w Brazylii 1871-1914 (Wrocław: Zakład Narodowy im. Ossolińskich, 1972); Krystyna Murzynowska, Polskie wychodźstwo zarobkowe w Zagłębiu Ruhry w latach 1880-1914 (Wrocław: Zakład Narodowy im. Ossolińskich, 1979); Józef Okołowicz, Wychodźtwo i osadnictwo polskie przed wojna światowa (Warszawa: Urząd Emigracyjny, 1920); Mieczysław Szawleski, Wychodźtwo polskie w Stanach Zjednoczonych Ameryki (Lwów-Warszawa-Kraków: Zakład Narodowy im. Ossolińskich, 1924).
} 
(permanent or seasonal) or the migration policy. ${ }^{4}$ There are very few studies on the total period 1870-1938; these are mainly syntheses of Polish emigration. ${ }^{5}$

It should be added that studies on emigration in the 19th century posed a number of difficulties, mostly due to the political status of Polish territories and the imperfect methods for registration of emigration, which can be referred to as a "source impairment," after Bobińska ${ }^{6}$ For Polish nationals, there was a problem identifying them from among all the citizens of Austria, Prussia/Germany or Russia. Therefore, migration censuses in immigration countries, using the criteria of the country of origin and nationality, became an important source of information. ${ }^{7}$ In the case of seasonal emigration, the fundamental source of data was legalization documents. Registration of emigrants was incomplete, but although from the end of the 19th century there was clear improvement, it did not include quite numerous illegal emigrants. Separating permanent emigration from seasonal emigration is also particularly difficult. The above-mentioned problems were on a much smaller scale in the interwar period, when the control and registration of emigrants was handed over to public institutions.

The article consists of two parts: the first referring to emigration in the period 1871-1914, and the second to the interwar period. Both present the characteristics of emigration processes (split into permanent and seasonal emigration), their main determinants and geographic directions. The most space is devoted to the origin of migrants by regions: in 1870-1914 by four regions (provinces) and middle-tier local units and in the interwar period by groups of voivodeships and by voivodeships.

${ }^{4}$ Adam Jarzyna, Polityka emigracyjna (Lwów: Skład „Dom Książki Polskiej,” 1933); Halina Janowska, Emigracja zarobkowa z Polski 1918-1939 (Warszawa: PWN, 1981); Halina Janowska, Polska emigracja zarobkowa we Francji, 1919-1939 (Warszawa: Książka i Wiedza, 1964); Celina Bobińska, ed., Mechanizmy polskich migracji zarobkowych (Warszawa: Książka i Wiedza, 1976); Samuel Fogelson, "Rola wędrówek w rozwoju demograficznym Polski," Ekonomista 1937, vol. 1.

${ }^{5}$ Marek M. Drozdowski, ed., Problemy dziejów Polonii (Warszawa: PWN, 1979); Andrzej Pilch ed., Emigracja z ziem polskich w czasach nowożytnych i najnowszych (XVIII-XX w.) (Warszawa: PWN, 1984); Hieronim Kubiak, Eugeniusz Kusielewicz, and Tadeusz Gromada, eds., Polonia amerykańska. Przeszłość i współczesność (Kraków-Wrocław: Zakład Narodowy im. Ossolińskich, 1988); Adam Walaszek, Migracje Europejczyków 1650-1914 (Kraków: Wydawnictwo Uniwersytetu Jagiellońskiego, 2007).

${ }^{6}$ Celina Bobińska, Wprowadzenie, in Celina Bobińska, ed., Mechanizmy polskich migracji, 16.

${ }^{7}$ Jan Derengowski, "Ruch migracyjny pomiędzy Polską a Stanami Zjednoczonymi Ameryki Północnej," Statystyka Pracy 1927, no. 1, 41. 


\section{The Great Migration 1870-1914}

Migrations of people in the 19th century that were not dictated by war or political reasons are among the most intensive migrations of people in Polish history. They took place within the whole territory of Poland. In the final decade of the 19th century and at the beginning of the 20th century they started to appear on a mass scale. Previously (until the 1880s), only the areas under Prussian rule showed higher migration activity. Their scale and directions were determined by a whole range of factors and circumstances, which can be split into factors and circumstances stimulating immigration and emigration: pull and push factors. ${ }^{8}$ Pull factors include widely interpreted settlement and earning conditions in immigration countries. Push factors included overpopulation of the Polish countryside (its scale was affected by a demographic explosion), deficiency of jobs in non-agricultural sectors, and sometimes the political situation and avoidance of military duty. ${ }^{9}$ The enlistment activities of emigration agents were also important. ${ }^{10}$

Emigration incurred costs of transport to the place of settlement and entry fees collected by immigration countries. Travelling conditions definitely improved at the beginning of the 20th century; migrants were also better protected against abuse. The first stage of the journey was reaching the checkpoints, mainly on the Prussian border. The emigrants underwent medical tests and had to fill in the relevant documents.

Polish emigrants left mostly for the US. Brożek recounts that they were driven by the urge to create a permanent home and had no intention of returning. ${ }^{11}$ The US ran a liberal immigration policy to which limitations were introduced with time. ${ }^{12}$ In 1907, deportation was first authorized, and an Immigration Committee was established to enforce and create immigration regulations. Despite the tightened-up regulations, every healthy newcomer who was capable of working was granted the right to enter. ${ }^{13}$ In the years $1871-1913,1.9$ million people left

\footnotetext{
${ }^{8}$ Andrzej Pilch, "Emigracja z ziem polskich do Stanów Zjednoczonych Ameryki od lat pięćdziesiątych XIX w. do r. 1918," in Polonia amerykańska, 38-39.

${ }^{9}$ Grzegorz M. Kowalski, "Prawna regulacja wychodźstwa w Królestwie Polskim w latach 1815-1914," Czasopismo Prawno-Historyczne 2003, no. 2, 237-238.

${ }^{10}$ Michał Starczewski, "Z dziejów emigracji zarobkowej: agenci emigracyjni na ziemiach polskich przed 1914 r.," Przeglad Historyczny 2012, no. 1, 47-80.

${ }^{11}$ Andrzej Brożek, "Ruchy migracyjne z ziem polskich pod panowaniem pruskim w latach 1850-1918," in Polonia amerykańska, eds. Hieronim Kubiak, Eugeniusz Kusielewicz, and Tadeusz Gromada (Kraków-Wrocław: Zakład Narodowy im. Ossolińskich, 1988), 170.

${ }^{12}$ Andrzej Brożek, "Polityka imigracyjna w państwach docelowych emigracji polskiej (18501939)," in Emigracja z ziem polskich (XVIII-XX w.), ed. Andrzej Pilch (Warszawa: PWN, 1984), 123.

${ }^{13}$ Adam Jarzyna, Polityka, 60-61.
} 
Polish provinces, including 1.3 million Poles. ${ }^{14}$ Their origin according to Polish provinces is shown in Table 1.

Table 1. Emigration from Poland to the US, 1871-1913

\begin{tabular}{|c|c|c|c|c|}
\hline \multirow{3}{*}{ Specification } & \multirow[b]{2}{*}{ Total } & \multicolumn{3}{|c|}{ From areas } \\
\hline & & $\begin{array}{l}\text { Austrian } \\
\text { partition }\end{array}$ & $\begin{array}{l}\text { Russian } \\
\text { partition }\end{array}$ & $\begin{array}{l}\text { Prussian } \\
\text { partition }\end{array}$ \\
\hline & \multicolumn{4}{|c|}{ thousands } \\
\hline \multicolumn{5}{|c|}{ Total emigration } \\
\hline Total & 1,900 & 900 & 950 & 50 \\
\hline Poles & 1,300 & 550 & 700 & 50 \\
\hline Ukrainians & 225 & 225 & . & . \\
\hline Jews & 375 & 125 & 250 & . \\
\hline \multicolumn{5}{|c|}{ Net emigration (excl. re-emigration) $)^{\mathrm{a}}$} \\
\hline Total & 1,500 & 650 & 800 & 50 \\
\hline Poles & 1,000 & 350 & 600 & 50 \\
\hline Ukrainians & 200 & 200 & . & . \\
\hline Jews & 300 & 100 & 200 & . \\
\hline
\end{tabular}

a It was assumed that re-emigrants accounted for at least $20-25 \%$ of all emigrants.

Source: Andrzej Brożek, Polonia amerykańska 1854-1939 (Warszawa: Interpress, 1977), 36.

The number of 1.9 million emigrants appears in many sources. However, the estimated numbers of emigrants according to particular regions vary. For instance, Fogelson indicated that 800,000 people left the Russian partition, 400,000 the Prussian partition and 700,000 the southern region (Galicia). ${ }^{15}$ According to US immigration statistics ${ }^{16}$ the number of Polish immigrants who arrived in the US from 1820 was, to $1870,3,700$, but to $1910,1,114,200 .{ }^{17}$ The actual number of Polish emigrants was higher. ${ }^{18}$ It is clear from US immigration

${ }^{14}$ Andrzej Brożek, Polonia amerykańska, 36.

${ }^{15}$ Samuel Fogelson, Rola wędrówek, 64.

${ }^{16}$ Until 1898 it used the category of Poland as a country (including people other than Poles). From 1899 immigrants from Polish territories were included in the groups of immigrants from Austria, Germany and from Russia. People entering the US were asked about their last country of stay. Annual Report of the Commissioner General of Immigration to the Secretary of Labor for the fiscal year ended 30 June 1922, US Department of Labor, Washington 1922, 26, 27, 100-101.

${ }^{17}$ Fiscal years: 01 July-30 June. Annual Report of the Commissioner General of Immigration to the Secretary of Labor for the fiscal year ended 30 June 1914, US Department of Labor, Washington $1915,38,50$.

${ }^{18}$ Andrzej Brożek, Ruchy migracyjne, 158-168; Andrzej Pilch, Emigracja z ziem polskich do Stanów Zjednoczonych Ameryki, 39; Adam Galos and Kazimierz Wajda, "Migrations in the Polish Western Territories Annexed by Prussia (1815-1914)," in Employment-seeking Emigrations of the 
statistics that from 1898, the criterion of the country of origin was introduced. The number of immigrants declaring themselves Poles who arrived in the US in 1899-1914 was 1,402,700, including 702,500 from the area under Russian rule (50.1\%), 560,300 from the area under Austrian and Hungarian rule (39.9\%), and 33,700 from the area under German rule (2.4\%), while there were 106,200 from other countries (7.8\%). ${ }^{19}$ The number of Poles in the US can also be estimated with reference to US censuses. Poland was indicated as the country of birth by 14,000 people in 1870 , which, by 1900 had risen to $383,600(154,400$ from the Russian state, 150,200 from the German state, 58,500 from the Austrian state and 20,400 from other countries). During the 1910 census, Polish was indicated as the mother language by 944,000 immigrants (418,000 from the Russian state, 329,000 from the Austrian state and 190,000 from the Prussian state). These statistics do not allow us to determine accurately the number of Poles who left the territory of Poland (split among three occupying states) for the US. The discrepancies follow from the application of different criteria of origin of the immigrants: in first place statehood only, and then nationality and the country of origin. The criterion of statehood in the situation where the Polish state did not exist is unreliable. More credibility can be given to statistics based on the declarations of nationality and the last country of stay. It must be also remembered that the group predominant among immigrants was peasants (more than $80 \%$ ). They were often illiterate and had problems determining their national affiliation. ${ }^{20}$

Canada was also an immigration country with immigration regulations similar to those of the US. The Canadian government supported the influx of agricultural workers, colonists and domestic service. The census in 1911 showed 33,700 Poles (Canadian of Polish origin). ${ }^{21}$ This number probably included Ruthenians from Galicia. Brazil became a popular destination for emigrants after 1875,

Poles World-Wide XIX and XX C., eds. Celina Bobińska and Andrzej Pilch, Zeszyty Naukowe Uniwersytetu Jagiellońskiego, Prace Polonijne, no. 1, (Kraków: PWN-UJ, 1975), 62.

${ }^{19}$ Annual Report of the Commissioner General of Immigration to the Secretary of Labor for the fiscal year ended 30 June 1891/92-1901/02, US Department of Labor, Washington 1892-1902; Annual Report of the Commissioner General of Immigration to the Secretary of Labor for the fiscal year ended 30 June 1907, US Department of Labor, Washington 1907; Annual Report of the Commissioner General of Immigration to the Secretary of Labor for the fiscal year ended 30 June 1914, US Department of Labor, Washington 1915; Annual Report of the Commissioner General of Immigration to the Secretary of Labor for the fiscal year ended 30 June 1922, US Department of Labor, Washington 1922.

${ }^{20}$ Krzysztof Groniowski, "Świadomość chłopskiej emigracji w Stanach Zjednoczonych do roku 1918," Acta Universitatis Lodziensis. Folia Historica 1992, no. 45, 157.

${ }^{21}$ Donald H. Avery and Jan K. Fedorowicz, Les Polonais au Canada, (Ottawa: Société Historique du Canada, 1982), 4-6. The total number of Polish immigrants who went to Canada during the period 1896-1910 was estimated at 110,000 (most of them came from Galicia, many people returned, while others went to the US). 
increasing greatly in the $1890 \mathrm{~s}$ - this period was referred to as the "Brazilian fever." It affected the Kingdom of Poland and Galicia. The first wave of emigration was recorded in 1890-1891, when about 45-50,000 people left the Kingdom of Poland. Emigration from Galicia grew in 1895-1896, extending to about 25,000 people, mostly Ruthenians. Another revival took place after 1907, when the Brazilian government again announced beneficial rules for colonization, including the possibility to choose the colony and free transport from a port in Europe. After 1905, the number of emigrants was swelled by people leaving the Kingdom of Poland because of the fear of repressions after the revolution of 1905. It is estimated that up to 1914, more than 130,000 people, including more than 100,000 Poles, left Polish territory for Brazil..$^{22}$ The number of Polish settlers in Argentina was estimated at 10,000 people. ${ }^{23}$

As regards Europe, Germany was the most popular immigration country. Apart from short-term periods of decline caused by economic crises, there was a continuing upward trend. The estimates of Poles staying in Germany differ. The highest estimate is that upon the outbreak of war their number was 850,000 including 750,000 people from areas under Prussian rule. ${ }^{24}$ The largest number of people, that is, 500,000, lived in the Ruhr District, about 200,000 in Central Germany and port cities, and about 100,000 in Berlin and the vicinity. ${ }^{25}$

For people from central Poland, Russia was also an immigration country. Gainful emigration started in the 1860s along with the birth of Russian industry. Major destinations were St. Petersburg, Moscow, Odessa, Riga, and the Donetsk District. Emigration to Siberia started in the 1880s. In 1909, a few thousand miners started leaving the Dąbrowa Basin. Low-scale emigration of peasants to the southeastern governorates and to Bessarabia also occurred. From the 1890s, people of Ukrainian nationality from the countryside in Eastern Galicia emigrated, often illegally (more than 3,500 people). Accurate data on the scale of emigration to Russia is not available. According to Fogelson, about 200,000 people emigrated. Russian censuses show that 339,000 Poles were living in Russia around 1910; the estimated number is $380,000{ }^{26}$

${ }^{22}$ Marcin Kula, "Ameryka bliska i daleka," in Emigracja, Polonia, Ameryka Eacińska: procesy emigracji i osadnictwa Polaków w Ameryce Łacińskiej i ich odzwierciedlenie w świadomości społecznej, ed. Tadeusz Paleczny (Warszawa: Uniwersytet Warszawski-CESLA, 1996), 55-60.

${ }^{23}$ Józef Okołowicz, Wychodźtwo, 249.

${ }^{24}$ Krystyna Murzynowska, "Polska emigracja zarobkowa w Niemczech w latach 1890-1918," in Problemy dziejów, ed. Marek M. Drozdowski, 159.

${ }^{25}$ Krystyna Murzynowska, Polska emigracja, 160-162; Krystyna Murzynowska, Polskie wychodźstwo, 31.

${ }^{26}$ Eugeniusz Romer, Ignacy Weinfeld, Rocznik Polski, tablice statystyczne (Kraków: Nakład Księgarni G. Gebethnera i Spółki, 1917), 6. 
The last, most significant destination for emigrants from Poland was the countries of the Austro-Hungarian Empire. The emigrants were mainly people from Galicia. Migration intensified at the beginning of the $1890 \mathrm{~s} .{ }^{27}$ According to Zamorski, the number of emigrants from Galicia heading for the Dual Monarchy reached $650,000 .{ }^{28}$ Austrian census data indicate that in 1900 the number of people from Galicia present in Cisleithania was about 186,000. ${ }^{29}$ Fogelson presents similar data (Table 2). Settlement-oriented emigration to other European countries was insignificant. In total, it is estimated at 50,000. Most headed for France; in 1890 it was about 6,000, while in 1913 the number was about $8-10,000(1,500$ from the Kingdom of Poland and the rest from Galicia)..$^{30}$ According to census information, in 1921 France had nearly 46,000 inhabitants of Polish nationality; this number is also inclusive of emigrants during the war. ${ }^{31}$

Fogelson presents synthetic figures for Polish emigration in 1870-1913. Based on public census information and migration statistics he estimated the "loss" of population. An estimate referring to a shorter period, i.e., 1895-1913, was given by Szulc. Table 2 illustrates both estimates.

Table 2. The population of Polish territories and migration "losses" in 1871-1913

\begin{tabular}{|c|c|c|c|c|c|}
\hline \multirow{2}{*}{ Specification } & \multirow{2}{*}{ Total } & \multicolumn{4}{|c|}{ Polish regions } \\
\hline & & Central & Eastern & Western & Southern \\
\hline 1 & 2 & 3 & 4 & 5 & 6 \\
\hline \multicolumn{6}{|c|}{ Total population in thousands } \\
\hline Population of Polish territories ca. $1895^{\mathrm{a}}$ & 24,019 & 9,589 & 4,338 & 3,256 & 6,836 \\
\hline Population of Polish territories ca. $1912^{\mathrm{a}}$ & 29,640 & 12,243 & 5,265 & 4,047 & 8,085 \\
\hline \multicolumn{6}{|c|}{ "Loss" of population due to migration in $1871-1913$ - Fogelson's estimate } \\
\hline Total & 3,500 & 700 & 550 & 1,200 & 1,050 \\
\hline Overseas emigration & 2,250 & 550 & 450 & 450 & 800 \\
\hline US & 1,900 & 450 & 350 & 400 & 700 \\
\hline Other countries & 350 & 100 & 100 & 50 & 100 \\
\hline
\end{tabular}

${ }^{27}$ Andrzej Pilch, "Trendy migracji zarobkowej ludności Galicji w XIX i XX w. (do 1918)," in Mechanizmy polskich migracji, ed. Celina Bobińska, 70-80.

${ }^{28}$ Krzysztof Zamorski, Transformacja demograficzna $w$ Galicji na tle przemian ludnościowych innych obszarów Europy Środkowej w drugiej połowie XIX i na początku XX w. (Kraków: UJ, 1991), 135.

${ }^{29}$ Krzysztof Zamorski, “Ludność Galicji w latach 1857-1910,” in Informator statystyczny do dziejów społeczno-gospodarczych Galicji, ed. Helena Madurowicz-Urbańska (Kraków-Warszawa: UJ-PTS, 1989), 178-179.

${ }^{30}$ Wiesław Śladkowski, Emigracja polska we Francji 1871-1918 (Lublin: Wydawnictwo Lubelskie, 1980), 19-29.

${ }^{31}$ Samuel Fogelson, "Robotnicy polscy we Francji w 1927 roku," Statystyka Pracy 1930, no. 4,400 . 


\begin{tabular}{lrrrrr}
\hline \multicolumn{1}{c}{1} & 2 & 3 & 4 & 5 & 6 \\
\hline European emigration & 1,250 & 150 & 100 & 750 & 250 \\
Germany & 850 & 50 & - & 750 & 50 \\
Russia & 200 & 100 & 100 & - & - \\
Austro-Hungarian Empire & 150 & - & - & - & 150 \\
Other countries & 50 & - & - & - & 50 \\
\hline \multicolumn{7}{c}{ Natural increase } & In 1895-1913-Szulc's estimate \\
Actual growth in population & 8,826 & 3,717 & 1,485 & 1,413 & 2,211 \\
"Loss" of population due to migration & 6,291 & 2,974 & 1,039 & 896 & 1,382 \\
As a \% of birth rate & 2,535 & $743^{c}$ & $446^{c}$ & 517 & 829 \\
\hline
\end{tabular}

a Migration "loss" is the difference between the actual growth in population and the natural increase.

${ }^{\mathrm{b}}$ Regions are comparable to the groups of interwar voivodeships: central, eastern, western and southern.

c Approximate estimates.

Note: the emigration movement from the area corresponding to the Second Polish Republic totaled 5 million people, of whom about 1.5 million re-emigrated or settled in the territory of Poland. Data compiled by Fogelson and by Szulc for the central district is inconsistent: numbers provided by Szulc for a period of about 20 years are higher than those reported by Fogelson with reference to a period longer than 40 years. According to Fogelson, the reasons behind the discrepancy are the different methods.

Source: Samuel Fogelson, "Rola wędrówek," 64; Stefan Szulc, "Zagadnienia demograficzne Polski. Ruch naturalny ludności w latach 1895-1935. Dokładność rejestracji urodzeń i zgonów," Statystyka Polski 1936, serie C, vol. 41, 8-10, 15; Maty Rocznik Statystyczny 1939 (Warszawa: GUS, 1939), 40.

Fogelson recounts that in 1871-1913 the "loss of population" caused by migrations amounted to 3.5 million people. Szulc reported that more than $70 \%$ occurred in the period 1895-1913. Overseas regions (mainly US) accounted for 64\% of the "loss," and European regions (mainly Germany) for 36\%. In absolute numbers, the emigration rate to the US was two times higher than to Germany. Emigration to Russia and Austria-Hungary was insignificant compared to emigration to the US and Germany. The 3.5 million people corresponded to $11.8 \%$ of Poland's population in $1912,29.7 \%$ for the western district, $13.0 \%$ for the southern district, $5.7 \%$ for the central district and $10.4 \%$ for the eastern district.

Emigration rates according to regions are also illustrated by population balance sheets based on censuses, taking emigration movements into account. Relevant statistics are available for the Prussian partition and for Galicia. They are presented in Table 3 (in the area under Russian rule only one census was carried out in 1897, hence, it is impossible to compare analogous statistics). In Galicia the largest scale of migration occurred in the last decade of the 19th century and in the first decade of the 20th century; in the area under Prussian rule large emigration rates were also recorded in previous decades. 
Table 3. Balance of migrations in Galicia (Austrian partition) and in the Polish provinces under Prussian rule in 1871-1910

\begin{tabular}{|c|c|c|c|c|c|c|}
\hline \multirow[b]{2}{*}{ Specification } & \multicolumn{2}{|c|}{$1871-1910$} & $1871-1880$ & $1881-1890$ & 1891-1900 & 1901-1910 \\
\hline & thousands & $\begin{array}{l}\text { as a percent } \\
\text { of the growth } \\
\text { in population }\end{array}$ & \multicolumn{4}{|c|}{ thousands } \\
\hline Galicia & $-857^{b}$ & $41.5^{\mathrm{b}, \mathrm{c}}$ & . & -55 & -305 & -496 \\
\hline Western Galicia & -468 & 81.2 & . & -74 & -169 & -224 \\
\hline Eastern Galicia & -388 & 26.1 & . & +20 & -136 & -272 \\
\hline $\begin{array}{l}\text { Prussian rule } \\
\text { Regierungsbezirk }\end{array}$ & $-1,344^{\mathrm{d}}$ & $148.5^{\mathrm{d}}$ & -221 & -430 & -356 & -337 \\
\hline Bydgoszcz & -271 & 137.6 & -48 & -87 & -67 & -72 \\
\hline Poznań & -483 & 151.4 & -78 & -146 & -152 & -108 \\
\hline Gdańsk & -160 & 73.4 & -26 & -63 & -25 & -45 \\
\hline Kwidzyń & -429 & 250.9 & -71 & -134 & -112 & -111 \\
\hline
\end{tabular}

a The ratio is the quotient of the growth in population and the balance of migration.

${ }^{\mathrm{b}}$ Excluding 1871-1880.

${ }^{\mathrm{c}}$ In 1901-1910 the ratio was 70\%, whereas for Western Galicia it was 133\%, and for Eastern Galicia 52\%.

${ }^{\mathrm{d}}$ In the comparable period with Galicia, 1881-1910, the negative balance of migration was 1,123,000, which given a growth in population by 695,000 makes $61.6 \%$.

Note: Zamorski also recounts the balance of migration for Galicia compared to the countries of the Austrian monarchy.

Source: Andrzej Jezierski and Andrzej Wyczański, eds., Historia Polski w liczbach, vol. 1, Państwo. Społeczeństwo (Warszawa: GUS, 2003), 184-185; Krzysztof Zamorski, Ludność Galicji, 180-183.

Tables 1-3 confirm that in 1870-1914 Poles emigrated on the largest scale from the Prussian partition. ${ }^{32}$ Their destination was mostly Germany. The second destination was the US and its popularity decreased after 1890 when German industrial centers increased in attractiveness. A part of those people settling in Germany derived from seasonal emigrants. Seasonal workers usually worked in agriculture in Eastern Germany but some of them also went to western industrial centers. Germany was mainly a destination chosen by people from the Polish borderland. Up to $20 \%$ of the population left the southern communes of the Poznan region. ${ }^{33}$ Those migrants tended to avoid Upper Silesia, due to worse working conditions. Upper Silesian industry employed local workers or migrants from

${ }^{32}$ In the Prussian state, migration statistics began to be conducted from 1844; they did not distinguish Polish nationality. Kazimierz Wajda, Migracje ludności wiejskiej Pomorza Wschodniego w latach 1850-1914 (Wrocław: Zakład Narodowy im. Ossolińskich, 1969).

${ }^{33}$ For example, from the Parish of Piłka every year, about $75 \%$ of adults went to work in Berlin and Dortmund. Alfons J. Parczewski, "Emigracja z wschodnich prowincji Monarchii pruskiej," Przeglad Emigracyjny 1892, no. 12, 23-125. 
Galicia and the Kingdom of Poland. ${ }^{34}$ According to Okołowicz, in 1895-1900, the number of Polish settlement-oriented emigrants in the Prussian state was 408,500: 146,600 came from East Prussia (7.4\% of the population in the province), 69,700 from Gdańsk Pomerania (4.6\%), 127,900 from the Poznań region (7.0\%), and 64,400 from Silesia (1.4\%). ${ }^{35}$

Galicia ranked second among the emigration districts of Poland. In popular opinion, the Galician emigration rate is perceived to be exceptionally high. However, as indicated above, it was lower than the emigration from the Polish provinces under Prussian rule both in absolute and relative terms. Its intensity was not the highest in the Habsburg Empire. ${ }^{36}$ Pilch recounts that from 1870 to 1914 at least 1.1 million people emigrated from Galicia, including about 900,000 people who travelled to overseas countries. According to Fogelson, in 1895-1913 about 900,000 people left Galicia, including 550,000 Poles. ${ }^{37}$ In turn, English estimated that in 1880-1910 as many as 860,000 people left their place of residence, including 468,000 in Western Galicia and 392,000 in Eastern Galicia. As many as 71\% of emigrants were Poles, and $29 \%$ Ruthenians. ${ }^{38}$ The predominant destinations were overseas countries ( $80 \%$ of all emigrants), including US (70\% of all emigrants). Overseas emigration existed from the mid- 1870s, and intensified in the 1890s. The second most popular destination for emigrants was Austria-Hungary and the third, after 1890 , Germany. ${ }^{39}$

As regards the quotas of emigrants, the Kingdom of Poland was the third. The subjects of the Romanov dynasty preferred emigration to overseas regions, especially to the US. Emigration started in the second half of the 1870 s, increasing after 1890. Initially, the emigrants were the inhabitants of northern governorates of the Kingdom and from the 1880s also of other governorates. Fogelson estimated that the total "loss" of the population was 700,000 (including 450,000 to the US, 100,000 to Russia, and 50,000 to Germany). He claimed that the number of emigrants from the entire area under Russian rule in 1895-1913 was 950,000 (including 700,000 Poles). ${ }^{40}$ The second emigration country was Russia. The number of Polish emigrants in Russia amounted to 600,000, of whom about 60,000 were in St. Petersburg (excluding 6,000 Polish soldiers), 24,000 in Odessa,

${ }^{34}$ Czesław Łuczak, Od Bismarcka do Hitlera. Polsko-niemieckie stosunki gospodarcze (Poznań: Wydawnictwo Poznańskie, 1988), 10-11.

${ }^{35}$ Józef Okołowicz, Wychodźtwo, 251-253.

${ }^{36}$ Krzysztof Zamorski, Transformacja demograficzna, 137-138.

${ }^{37}$ Andrzej Pilch, "Emigracja z ziem zaboru austriackiego (od połowy XIX w. do 1918 r.)," in Emigracja z ziem polskich, ed. Andrzej Pilch (Warszawa: PWN, 1984), 269.

${ }^{38}$ Leopold Caro and Karol English, Emigracja i polityka emigracyjna ze szczególnem uwzględnieniem stosunków polskich (Poznań: Drukarnia i Księgarnia Św. Wojciecha, 1914), 23-24.

${ }^{39}$ Andrzej Pilch, "Trendy migracji," 70-80.

${ }^{40}$ Samuel Fogelson, "Rola wędrówek," 62. 
20,000 in Riga, with the rest living in smaller cities. ${ }^{41}$ The emigration was mainly non-agricultural and included public officials, engineers and tradespeople as well as laborers and craftspeople. The worker emigration rate increased from the early 20 th century. It is estimated that $30-35 \%$ of all Polish emigrants in Russia were blue-collar workers. ${ }^{42}$

All the above figures referring to the Kingdom and Galicia are not inclusive of seasonal emigrants. Germany was their favored destination. Seasonal emigration to Russia was definitely less significant (it developed at the turn of the century and covered the southern governorates of the Kingdom and Eastern Galicia) and to the countries of the Dual Monarchy. Emigration to Germany was regulated by German immigration policy. An arrivals control system was in place. Its restrictiveness was a derivative of the situation in the German employment market. ${ }^{43}$ Polish workers were obliged to return to Poland after summer employment in the fields. Workers were recruited by the Labor Exchange as well as by chambers of agriculture, private agents and various offices. In 1907, a compulsory identity card system was introduced. It applied to workers from all countries and was strictly applied in relation to newcomers from the Congress Kingdom and from Galicia. Data for the years directly preceding the war regarding workers from the Kingdom and from Galicia are given in Table 4. The figures are not inclusive of the whole of Germany, but they reflect the scale of seasonal emigration and employment of workers in agriculture and industry.

Fogelson estimates that during the 20 years before the war, the total number of seasonal workers in Germany could have been 3-4 million. ${ }^{44}$ According to Jarzyna, the number of Polish workers employed in Germany (temporarily or on a long-term basis) before the outbreak of war was 600,000 people: $58 \%$ came from the Kingdom of Poland, 34\% from Galicia, and only $8 \%$ from the Prussian partition. ${ }^{45}$ Emigration for work purposes at the end of the 19th century reached a few thousand people per year from each region of Poland; in the first decade of the 20th century from 100,000 to 300,000 people emigrated from Galicia and from the Kingdom of Poland ${ }^{46}$ As regards emigration from the Kingdom of Poland, the largest number of workers was recruited from the governorate of Kalisz, Płock and Łomża. According to the Warsaw Statistical Committee, the average num-

\footnotetext{
${ }^{41}$ Józef Okołowicz, Wychodźtwo, 368-369.

${ }^{42}$ Zygmunt Łukawski, Ludność polska w Rosji 1863-1914 (Wrocław: Zakład Narodowy im. Ossolińskich, 1978), 43-50.

${ }_{43}$ Andrzej Brożek, Polityka imigracyjna, 121-122.

${ }^{44}$ Samuel Fogelson, "Rola wędrówek," 65.

${ }^{45}$ Adam Jarzyna, Polityka emigracyjna, 65; Anna Poniatowska, Polskie wychodźstwo sezonowe na Pomorzu Zachodnim (Poznań: Wydawnictwo Poznańskie, 1971), 55.

${ }^{46}$ Adam Jarzyna, Polityka emigracyjna, 65.
} 
ber of workers temporarily migrating to Germany in 1900-1902 was 132,000 , of whom (in thousands) 65 were from the Kalisz governorate, 26 from Płock, 16 from Łomża, and 13 from Piotrków. As calculated per 100 population: 3.1 for the whole Kingdom, 8.9 for the Płock governorate, 5.7 for the Płock governorate, 3.1 for Łomża and 1.4 for Piotrków governorate. ${ }^{47}$

Table 4. Identity cards issued to workers from the Kingdom of Poland and Galicia by the German Labor Exchange, 1908-1913

\begin{tabular}{lrrrrr}
\hline \multirow{2}{*}{ Specification } & $1908 / 09$ & $1909 / 10$ & $1910 / 11$ & $1911 / 12$ & $1912 / 13$ \\
\cline { 2 - 6 } & 292.8 & 323.3 & 330.7 & 357.6 & 358.5 \\
\hline Total & 212.2 & 239.9 & 253.1 & 281.8 & 283.4 \\
\hline Poles from the Russian state working in: & 197.0 & 223.7 & 237.7 & 259.3 & 259.4 \\
$\quad$ - agriculture & 15.2 & 16.2 & 15.4 & 22.5 & 24.0 \\
$\quad$ - industry & 80.6 & 83.4 & 77.6 & 75.8 & 75.1 \\
\hline Poles from the Austro-Hungarian state & 62.8 & 65.5 & 61.2 & 56.3 & 56.9 \\
working in: $^{\text {a }}$ & 17.8 & 17.9 & 16.3 & 19.5 & 18.2 \\
$\quad$ - agriculture & \multicolumn{5}{c}{ percent of total number of identity cards } \\
$\quad$ industry & 72.48 & 74.19 & 76.24 & 78.80 & 79.07 \\
& 27.52 & 25.81 & 23.76 & 21.20 & 20.93 \\
\hline
\end{tabular}

a Excluding Ukrainian nationals, their number in 1912/13 was 91,400, including 51,500 farm workers, and 39,800 industrial workers.

Source: J. Okołowicz, Wychodźtwo, 259-262.

Workers from Galicia and from the Kingdom of Poland were the largest group of nationalities among non-German seasonal workers: the number of identity cards issued to them in 1912/13 $(358,500)$ accounted for more than $50 \%$ of all identity cards $(767,200)$; Polish workers accounted for $75 \%$ of all farm workers. ${ }^{48}$ It must be mentioned that after the outbreak of war in 1914, German authorities did not allow about 300,000 Polish workers from the Kingdom of Poland to leave Germany. This was related to the needs of the German economy. ${ }^{49}$

47 "Statistique de l'émigration temporaire des ouvriers de 1900 à 1903 ses causes et son influence sur l'aisance de la population rurale de la région," Travaux du Comité Statistique à Varsovie 1902/03, no. XIX, 19.

${ }^{48}$ The share of Poles among foreign workers was up to 90\%. Władysław Skowron, Emigracja sezonowa do Niemiec jako zagadnienie spoteczne i gospodarcze (Warszawa: published by the author, 1931), 5, 7.

${ }^{49}$ Piotr Kraszewski, "Problem sezonowego wychodźstwa polskich robotników rolnych do Niemiec w latach 1919-1932,” Przegląd Zachodni 1985, no. 4, 26. 
Seasonal emigrants from the Kingdom of Poland would also go to countries other than Germany (Sweden, Austria and other countries, and also overseas countries). Related statistics were published by Warsaw Statistical Committee and the statistical office of the Russian Customs Department. These offices based their estimates on different sources so the figures they reported were highly inconsistent: according to Warsaw Statistical Committee, in 1900-1905 the emigration of seasonal workers increased from 119,000 to 200,000, while the Customs Department claimed it was from 87,000 to 397,000 . In addition, seasonal workers from Galicia went to other countries: to the Kingdom of Poland, to the states of the Dual Monarchy and even to Denmark, France, Sweden or Switzerland, and they were partially transformed into settlement-oriented emigrants. The rate of emigration increased from the $1880 \mathrm{~s}^{50}$

\section{The Breakdown of Emigration in the Interwar Period and a Change in its Directions}

Polish emigration policy in the interwar period distinguished between two basic types of emigration: settlement-oriented emigration (in principle equivalent to overseas emigration) and seasonal emigration (in principle equivalent to European emigration). Institutions dealing with the control of emigration and the care of emigrants were established. Agitation and the recruitment of emigrants by private companies were prohibited. ${ }^{51}$ At the same time, emigration policy evolved in response to the situation in the domestic employment market and the evolution of immigration countries' policies. ${ }^{52}$ The overall rate of emigration, including to the US and Germany, significantly decreased; emigration to Austria or Russia (USSR) ceased entirely. Emigration to France and Belgium grew and overseas emigration changed its direction to the countries of South America.

Emigration policy was carried out by the Ministry of Labor and Social Welfare and the Ministry of Foreign Affairs, implemented and coordinated by the Emigration Office (EO), formed in 1920. Emigration matters as a whole were governed by a Regulation of the President of the Republic of Poland from 1927. They were a responsibility of the EO, with its subordinated agencies and emigration stages at the main border checkpoints and labor exchange offices. Emigrants received special emigration passports issued free of charge, based on a certificate from the EO or labor exchange offices. Hiring workers for paid work abroad

\footnotetext{
${ }^{50}$ Adam Jarzyna, Polityka emigracyjna, 65; Józef Okołowicz, Wychodźtwo, 258.

${ }^{51}$ Halina Janowska, Emigracja zarobkowa, 103.

${ }^{52}$ Edward Kołodziej, Wychodźstwo zarobkowe z Polski 1918-1939. Studia nad polityka emigracyjna II Rzeczypospolitej (Warszawa: Książka i Wiedza, 1982), 43-44.
} 
required permission from the EO. The process of recruitment took place with the participation of labor exchange offices. The worker received a contract containing specific information (country and company of employer, salary etc.). During the Great Depression the organization of emigration underwent a change. Emigration policy evolved towards support for settlement. EO was disestablished by Presidential Regulation in 1932. Emigration matters outside Poland were handed over to the Ministry of Foreign Affairs, while internal affairs remained within the competence of the Ministry of Labor and Social Welfare. The Ministry of Labor and Social Welfare was still responsible for determining emigration quotas and their repartition between voivodeships, issuing permits to hire workers, organizing their transportation and maintaining emigration statistics. Field supervision was a task of the voivodes (regional governors) by means of emigration inspectors. $^{53}$

The tools of emigration policy were agreements and conventions signed with immigration countries: France (1919), Austria (1921), Belgium (1923: an agreement with the association of mine owners), Germany (1927), Brazil (1927: an agreement with the office of agriculture), Bolivia (1937), Estonia (1938) and Latvia (1938). ${ }^{54}$ Agreements from the 1920s regulated the existing state of affairs and those from the late 1930s determined the terms of new settlement-oriented emigration. In addition, agreements concerning the legal protection of emigrants were signed (accidents at work, pension insurance etc.). Financial support to settlers provided by an emigration fund and cheap loans (for settlers in South America) must also be mentioned. ${ }^{55}$

In the interwar period, the rate of emigration to the US radically decreased as a result of a tightened US immigration policy. Previously applicable qualitative criteria were replaced by quantitative measures when immigrant quotas were introduced: in 1921 these were 3\% of people according to the place of origin based on the 1910 census, while in 1924 these were $2 \%$, whereas for countries of Central and Eastern Europe and Southern Europe, the basis was data from the 1890 census when immigrants from those countries accounted for a small percentage of the US population. Quotas for Poland in 1922-1924 ranged from 26,000 to 31,000 people, but after 1924 they were reduced to about 6,000 (they were not inclusive

${ }^{53}$ Dz. U. 1932, no. 55/541.

${ }^{54}$ The Polish government also conducted negotiations with other South American countries, with Canada, the US, Great Britain and even Japan; however, they did not come to fruition.

${ }^{55}$ Piotr Puchalski, "Polityka kolonialna międzywojennej Polski w świetle źródeł krajowych i zagranicznych: nowe spojrzenie (1918-1945)," Res Gestae. Czasopismo Historyczne 2018, no. 7, 68-83; Jerzy Łazor, "Polityka migracyjna Drugiej Rzeczypospolitej - próba syntezy," in Od kwestii robotniczej do nowoczesnej kwestii socjalnej. Studia z polskiej polityki społecznej XX i XXI wieku, vol. III, ed. Paweł Grata (Rzeszów: Wydawnictwo Uniwersytetu Rzeszowskiego, 2015), $48-52$. 
of wives and children of US citizens and representatives of certain occupations). ${ }^{56}$ In the 1930s limitations occurred in connection with the Great Depression.

In the interwar period, emigration to Germany also decreased, the reasons being poor Polish and German relations and the difficult economic situation in Germany. Emigration was mainly seasonal despite the fact that until 1927 Poland and Germany lacked an agreement governing emigration. The German state tolerated emigration to meet the expectations of landowners. On the other hand, foreign workers were not allowed to stay in Germany in winter. ${ }^{57}$ Workers could be only employed in sectors with a labor deficit. A worker going to Germany had to carry a "travel list" issued by the border office, or a passport with a German visa; workers staying in Germany had to carry an identity card. Since the Polish authorities did not issue passports when they did not allow workers to leave, illegal emigration developed based on the German "travel list." In 1924, the Germans applied an immigration quota for Polish farm workers, determined every year. After the outbreak of a trade war between Germany and Poland in 1925, the pressure on landowners to send workers back to Poland after the end of the season increased. Throughout that time, Poland and Germany conducted talks concerning the overall regulation of seasonal migration. In 1927, an emigration convention was signed, in which immigration quotas and the procedures for determining them were set out (the quota for 1928 was 86,000 and for 1929 it was 65,000) along with the rules of recruitment, performed by Polish labor exchange offices. ${ }^{58}$ Polish workers were expected to have identical social rights as German workers.

The Polish authorities assumed that seasonal emigration could be a tool to reduce unemployment through the proper distribution of quotas. This was a difficult task, because for several decades emigration had been a natural phenomenon, mainly affecting poviats neighboring on Germany, e.g., in the Łódź voivodeship. There was a planned redeployment of "recruitment to the east"; however, due to the outbreak of the crisis and the breakdown of emigration, it was very difficult to implement the plans.

During the Great Depression, German immigration policy was tightened. In 1930-1931 the emigration quota was reduced (in 1931 by 30\%), and in 1932 the border was closed for seasonal immigrants and the convention from 1927 was terminated. Only workers with the right of permanent stay in Germany could be hired; others had to go back to Poland. The policy changed only in June 1937, 39-40.

${ }^{56}$ Andrzej Brożek, Polityka imigracyjna, 132-133; Jan Derengowski, "Ruch migracyjny,"

${ }^{57}$ Anna Poniatowska, Polskie wychodźstwo, 61-63.

${ }^{58}$ Włodzimierz Spaleniak, "Prawno-polityczne aspekty emigracji sezonowej polskich robotników rolnych do Niemiec w latach 1919-1939," Annales Universitatis Mariae Curie-Skłodowska 2002, vol. IX, 49-55, 57-58. 
when the governments of Poland and Germany signed an agreement resuming seasonal emigration. The quota was determined as 10,000 people from 17 poviats. The quota for 1938 was 60,000 people from 57 poviats. In November 1938 the German authorities submitted a proposal that 3,500 Polish workers could stay in Germany in the wintertime, but the Polish authorities rejected the offer. In February 1939, based on the convention from 1927, an agreement was signed providing for the possibility of employing 90,000 workers in Germany. When, in April 1939, Hitler broke off the Polish-German Non-Aggression Pact, the Polish authorities imposed a ban on traveling to Germany. ${ }^{59}$

As regards emigration to France, its development resulted from a drop in the French population due to the First World War. It was regulated by the PolishFrench convention signed in October $1919 .{ }^{60}$ The governments of both countries declared that they would facilitate gainful emigration and re-emigration, allowing the mass contracting of workers and individual migration. Polish workers were to have identical rights and receive identical pay to French workers in a specific workplace.${ }^{61}$ Contracted emigration was subject to annual quotas. ${ }^{62}$ Workers were taken to enlistment points and then transported to France (by ship or railway). ${ }^{63}$ Individual work permits could also be obtained; these were issued by the French ministries of labor and agriculture. ${ }^{64}$ During the Great Depression, the French authorities started removing foreign workers, who were mostly miners. In 1934, foreigners were no longer hired for public works and in 1935 they were made to leave the country (workers' cards were not renewed for people who had worked in France for fewer than 10 years). ${ }^{65}$ A large number of the contracts (more than $40 \%$ ) were terminated on average after 2 months. Some emigrants left for Belgium (coal mining). ${ }^{66}$

Let us now move to emigration statistics and the distribution of emigrants according to voivodeships. While emigration statistics were kept from 1919, their quality gave rise to many objections. It was only from 1925 that emigration was

${ }^{59}$ Włodzimierz Spaleniak, "Prawno-polityczne," 61-63.

${ }^{60}$ Dz. U. 1920, no. 41/246; Piotr Kraszewski, "Polsko-francuska konwencja emigracyjna z 3 września 1919 roku," Studia Polonijne 1972, no. 2, 103-104.

${ }^{61}$ Piotr Kraszewski, Polska emigracja zarobkowa w latach 1870-1939. Praktyka i refleksja (Poznań: Zakład Badań Narodowościowych PAN, 1995), 171-173.

${ }^{62}$ Stanisław Jurkiewicz, Polski ruch, 12-17.

${ }^{63}$ Jerzy Dzieciuchowicz, "Polonia francuska - ewolucja struktury przestrzennej i demograficzno-społecznej," Acta Universitatis Lodziensis. Folia Geographica Socio-Oeconomica 2000, no. 3,34 .

${ }^{64}$ Samuel Fogelson, "Wędrówki międzynarodowe," 23.

${ }^{65}$ Maria Niemyska, Remigracja z Francji w dobie kryzysu: na tle wyników ankiety 1936 roku (Warszawa: Instytut Gospodarstwa Społecznego, 1939), 40-45.

${ }^{66}$ Edward Kołodziej, Wychodźstwo zarobkowe, 100. 
registered according to voivodeships. From 1927, permanent emigration was registered separately from seasonal emigration. Therefore, the respective data for the years 1919-1926 are based on estimates. The rate of emigration according to groups of voivodeships is illustrated in Table 5 .

Table 5. Permanent and seasonal emigration according to groups of voivodeships in 1919-1938

\begin{tabular}{|c|c|c|c|c|c|c|}
\hline \multirow{3}{*}{ Specification } & \multirow{2}{*}{ Poland } & \multicolumn{4}{|c|}{ Voivodeships } & \multirow{2}{*}{ Unknown } \\
\hline & & Central & Eastern & Western & Southern & \\
\hline & \multicolumn{6}{|c|}{ thousands } \\
\hline \multicolumn{7}{|c|}{ Years 1927-1938 (official data) } \\
\hline Total & 1,312 & 554 & 210 & 193 & 351 & 4 \\
\hline Permanent (non-seasonal) & 778 & 279 & 127 & 85 & 283 & 4 \\
\hline \multicolumn{7}{|l|}{ Including to: } \\
\hline France & 337 & 122 & 13 & 63 & 136 & 3 \\
\hline US & 46 & 20 & 8 & 2 & 16 & 0 \\
\hline Seasonal & 534 & 275 & 83 & 108 & 68 & 0 \\
\hline Including to Germany & 431 & 264 & 0 & 108 & 59 & 0 \\
\hline \multicolumn{7}{|c|}{ Years 1919-1926 (estimate) } \\
\hline Total & 727 & 345 & 84 & 72 & 185 & 41 \\
\hline Permanent (non-seasonal) & 682 & 304 & 84 & 70 & 183 & 41 \\
\hline \multicolumn{7}{|l|}{ Including to: } \\
\hline France & 282 & 131 & 5 & 52 & 91 & 3 \\
\hline US & 227 & 102 & 48 & 2 & 71 & 5 \\
\hline Seasonal (Germany) & 45 & 41 & 0 & 2 & 2 & 0 \\
\hline \multicolumn{7}{|c|}{ In total, years 1919-1938 } \\
\hline Total & 2,039 & 899 & 294 & 265 & 536 & 45 \\
\hline Permanent (non-seasonal) & 1,460 & 583 & 211 & 155 & 466 & 45 \\
\hline \multicolumn{7}{|l|}{ Including to: } \\
\hline France & 619 & 253 & 18 & 115 & 227 & 6 \\
\hline US & 273 & 122 & 56 & 4 & 87 & 5 \\
\hline Seasonal & 579 & 316 & 83 & 110 & 70 & 0 \\
\hline
\end{tabular}

Note: based on official data from the Central Statistical Office; the literature gives slightly different numbers for the period 1918-1938, which is mostly the result of different estimates for emigration immediately after the war, and seasonal emigration.

Source: Mały Rocznik Statystyczny 1939, 52-53; Roczniki Statystyki Rzeczypospolitej Polskiej of: 1923, 25-27; 1925/1926, 100; 1927, 98; 1928, 72; 1929, 24; 1930, 33; "Statystyka Pracy" of: 1932 , no. $1,102-104 ; 1933$, no. 1,$45 ; 1934$, no. 1,$38 ; 1935$, no. $1,60-62 ; 1936$, no. 1,$53 ; 1937$, no. 1 , 68 ; 1938, no. 1,25 .

Based on official data, permanent and seasonal emigration in 1919-1938 can be estimated at 2.1 million people, including about 1.5 million permanent 
emigrants and 0.6 million seasonal emigrants. The latter figure is certainly underestimated, as it covers lawful emigration only. Jarzyna estimates the average annual number of Polish seasonal workers in Germany from 1919-1929 as 110,000 people; in total, from $1919-1929$ it was 1.2 million. ${ }^{67}$ A significant proportion of people left for work every year, so the summary data refer rather to the number of departures than to the number of emigrants. Workers from Poland accounted for $90 \%$ of all foreign workers.

As regards the balance of emigration, it is difficult to determine accurately, given the mixed (seasonal and settlement-oriented) nature of some departures to European countries. However, it can be indicated for selected countries: for France it was about $-410,000^{68}$ (as regards returns, only the data for the years 1925-1938 were taken into account), for non-European countries $-578,000$, in total $-988,000$. The balance of emigration in the years 1924-1938 (excluding postwar repatriation) can be estimated at $-704,000 .{ }^{69}$ Also, the "loss" of population can be estimated by comparing the actual population of Poland with its potential population taking into account a growth in the population from births. Data comparable with Table 2 is shown in Table 6.

Table 6. Natural increase and actual growth in population versus emigration 1919-1938

\begin{tabular}{|c|c|c|c|c|c|}
\hline \multirow{3}{*}{ Years } & \multirow{2}{*}{ Poland } & \multicolumn{4}{|c|}{ Voivodeships } \\
\hline & & Central & Eastern & Western & Southern \\
\hline & \multicolumn{5}{|c|}{ thousands } \\
\hline 1 & 2 & 3 & 4 & 5 & 6 \\
\hline \multicolumn{6}{|c|}{ Natural increase } \\
\hline 1919-1938 & 8,205 & 3,445 & 1,698 & 1,181 & 1,881 \\
\hline 1919-1923 & 1,508 & 659 & 249 & 282 & 318 \\
\hline 1924-1930 & 3,411 & 1,421 & 748 & 454 & 788 \\
\hline $1931-1938$ & 2,286 & 1,365 & 701 & 445 & 775 \\
\hline \multicolumn{6}{|c|}{ Actual growth in population ${ }^{a}$} \\
\hline 1919-1938 & 8,567 & 3,653 & 2,306 & 901 & 1,707 \\
\hline 1919-1923 & 2,492 & 1,027 & 960 & 102 & 403 \\
\hline 1924-1930 & 2,894 & 1,288 & 678 & 368 & 560 \\
\hline $1931-1938$ & 3,181 & 1,338 & 668 & 431 & 744 \\
\hline
\end{tabular}

${ }^{67}$ Adam Jarzyna, Polityka, 92.

${ }^{68}$ The number of people of Polish nationality according to the French census in 1936 was 422,700. Jerzy Dzieciuchowicz, "Polonia," 33.

${ }^{69}$ In 1924-1938, emigration to France and non-European countries amounted to 979,000, with re-emigration 275,000 . 


\begin{tabular}{cccccr}
\hline 1 & 2 & 3 & 4 & 5 & 6 \\
\hline \multicolumn{7}{c}{ Increase $(+)$} & or loss $(-)$ & as a result of migration \\
\hline $1919-1938$ & +362 & +208 & +608 & -280 & -174 \\
\hline $1919-1923$ & +984 & +368 & +711 & -180 & +85 \\
$1924-1930$ & -517 & -133 & -70 & -86 & -228 \\
$1931-1938$ & -105 & -27 & -33 & -14 & -31 \\
\hline
\end{tabular}

${ }^{a}$ Calculated as the difference between the population as of 1 January in indicated periods; population including quartered military forces.

Source: Mały Rocznik Statystyczny 1939, 40.

In 1919-1938 the "balance of migration" was positive $(+362,000)$, but this was the result of the positive balance of post-war immigration (in 1919-1923 it amounted to $+984,000) \cdot{ }^{70}$ In $1924-1938$ the balance was negative, at $-622,000$, so the "loss" of population caused by emigration processes amounted to 0.6 million. This means that emigration was an important depopulating factor, but its significance was smaller than in post-war years: in 1895-1913 it accounted for $29 \%$ of the growth in population from births, and in $1924-1938$ less than $10 \%{ }^{71}$ The rate of emigration was subject to very strong fluctuations, as a result of the economic situation in immigration countries. It was determined to a lesser extent by the situation in Poland. This is proved by the fact that the largest rate of emigration was observed in 1926-1929, that is, during the period of economic boom in Poland. The rate went down during the Great Depression and increased again only at the end of the 1930s (Figure 1).

Let us now move to analyzing emigration according to voivodeships. As shown in Table 6, the "loss" of population affected southern and central voivodeships to the greatest extent, while in eastern and western voivodeships it was half as much. As regards the rate of permanent emigration (Table 5), it was the highest in central voivodeships $(583,000)$, then southern $(466,000)$, eastern $(211,000)$ and western $(155,000)$. Its distribution according to the respective voivodeships is illustrated in Table 7.

The data show the most active migration statistics for the population of Łódź voivodeship, as regards both permanent and seasonal emigration. Poznań and Kielce voivodeships ranked second. The rate of seasonal emigration was also considerable in Vilnius voivodeship, from which people left to work in the Baltic states, including Latvia. On the other hand, the southern and eastern voivodeships were characterized by a high rate of non-seasonal emigration to overseas countries.

\footnotetext{
${ }^{70}$ Post-war repatriations amounted to around 1,182,000. Maty Rocznik Statystyczny, 52.

${ }^{71}$ Maty Rocznik Statystyczny, 40.
} 
Figure 1. Permanent and seasonal emigration according to immigration countries in $1918-1938$

A. Permanent and seasonal emigration ${ }^{\mathrm{a}}$

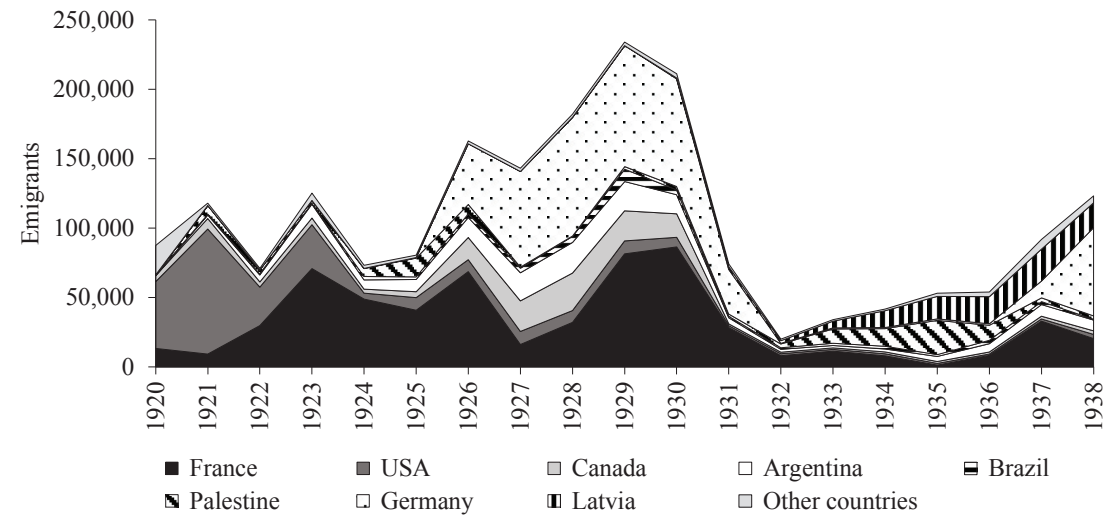

${ }^{a}$ Germany and Latvia - seasonal emigration.

B. Permanent emigration

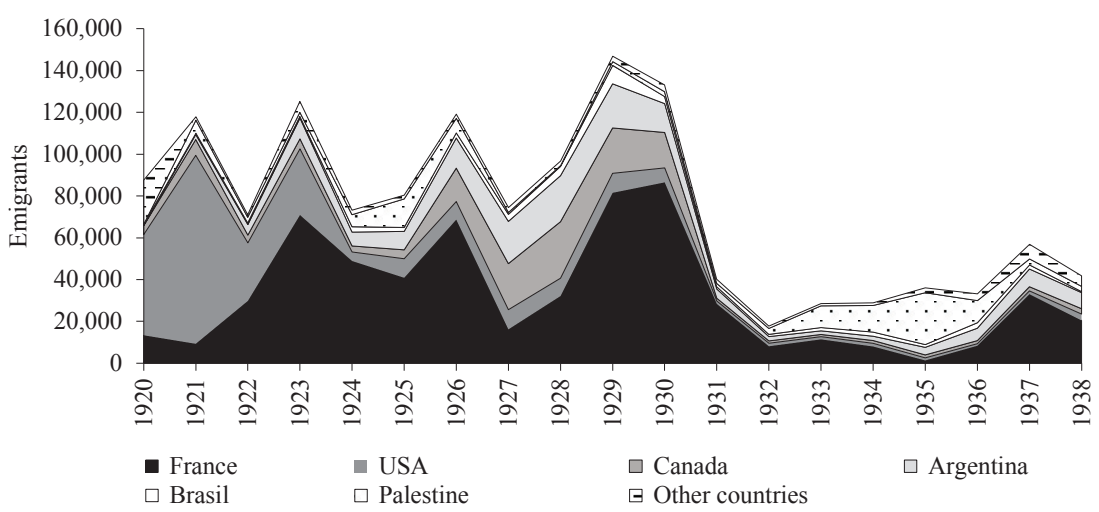

Source: calculations based on statistical yearbooks of the Central Statistical Office and "Statystyka Pracy" as in Table 5. 
Table 7. Permanent and seasonal emigration according to voivodeships in $1927-1938^{\mathrm{a}}$

\begin{tabular}{|c|c|c|c|c|c|c|}
\hline \multirow{4}{*}{ Voivodeships } & \multicolumn{6}{|c|}{ Emigration in $1927-1938$} \\
\hline & \multicolumn{4}{|c|}{ thousands } & \multicolumn{2}{|c|}{$\begin{array}{l}\text { percent of the population } \\
\text { according to the } 1931 \\
\text { census }\end{array}$} \\
\hline & \multicolumn{2}{|c|}{ seasonal } & \multicolumn{2}{|c|}{ non-seasonal } & \multirow{2}{*}{$\begin{array}{l}\text { in total } \\
\text { seasonal }\end{array}$} & \multirow{2}{*}{$\begin{array}{c}\text { in total } \\
\text { non-seasonal }\end{array}$} \\
\hline & total & $\begin{array}{l}\text { including } \\
\text { to Germany }\end{array}$ & total & $\begin{array}{l}\text { including } \\
\text { to France }\end{array}$ & & \\
\hline Poland & 533.8 & 431.2 & 777.8 & 335.5 & 1.7 & 2.4 \\
\hline Capital city of Warsaw & 0.3 & 0.3 & 33.5 & 5.9 & 0.0 & 2.9 \\
\hline Białostockie & 6.4 & 6.0 & 30.4 & 5.9 & 0.4 & 1.8 \\
\hline Kieleckie & 82.6 & 78.8 & 58.9 & 28.3 & 2.8 & 2.0 \\
\hline Krakowskie & 35.7 & 34.2 & 62.2 & 41.2 & 1.6 & 2.7 \\
\hline Lubelskie & 5.3 & 2.0 & 35.7 & 8.0 & 0.2 & 1.4 \\
\hline Lwowskie & 26.8 & 21.3 & 128.8 & 76.1 & 0.9 & 4.1 \\
\hline Lódzkie & 171.8 & 170.2 & 79.4 & 56.5 & 6.5 & 3.0 \\
\hline Nowogródzkie & 9.2 & 0.2 & 15.1 & 3.5 & 0.9 & 1.4 \\
\hline Poleskie & 0.4 & 0 & 29.2 & 0.4 & 0.0 & 2.6 \\
\hline Pomorskie & 13.8 & 13.6 & 20.9 & 14.5 & 1.3 & 1.9 \\
\hline Poznańskie & 90.4 & 90.1 & 58.8 & 45.2 & 4.3 & 2.8 \\
\hline Stanisławowskie & 3.0 & 3.0 & 27.6 & 5.2 & 0.2 & 1.9 \\
\hline Śląskie & 3.9 & 3.9 & 5.3 & 3.0 & 0.3 & 0.4 \\
\hline Tarnopolskie & 2.0 & 0.4 & 64.5 & 13.0 & 0.1 & 4.0 \\
\hline Warszawskie & 8.8 & 7.0 & 40.5 & 17.2 & 0.2 & 1.1 \\
\hline Wileńskie & 72.8 & 0 & 22.9 & 7.8 & 5.7 & 1.8 \\
\hline Wołyńskie & 0.5 & 0.1 & 60.0 & 1.1 & 0.0 & 2.9 \\
\hline Unknown & 0.1 & 0.1 & 3.9 & 2.7 & $\times$ & $\times$ \\
\hline
\end{tabular}

${ }^{a}$ Data for the years 1925-1926 were not included because they are not split into permanent and seasonal emigration.

Note: data based on the place of passport issue.

Source: Maty Rocznik Statystyczny 1939, 54; Rocznik Statystyczny RP 1927, 98.

The main immigration country for the inhabitants of most voivodeships was France, followed by overseas countries including the US, but also South American countries. This is illustrated by Figure 2 . 
Figure 2. Permanent emigration by groups of voivodeships and countries, 1918-1938

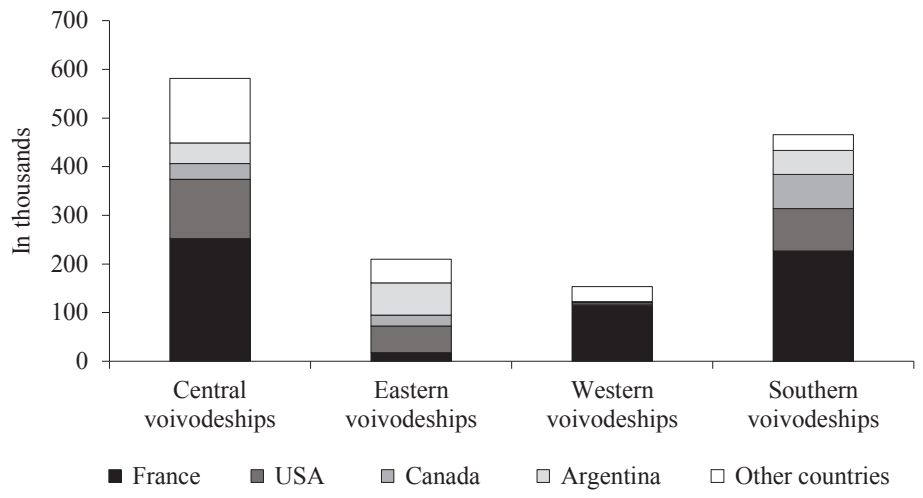

Source: as in Table 5.

Finally, the characteristics of seasonal emigration must be mentioned in brief. Seasonal emigrants were mainly farmers (accounting for 54\% of the group of professionally active people). ${ }^{72}$ Emigrants going to Germany predominantly came from three voivodeships: Łódź, Kielce, and Poznań. This was the result of prewar tradition and migration networks. In the period of maximum emigration intensity, 1926-1931, workers from Łódź voivodeship accounted for 53\% of the total number of emigrants (about 395,000 people), from Kielce voivodeship, 21\%, and from Poznań voivodeship, 10\%. In 1918-1926, every year about 80,000 Polish farm workers worked in Germany, where they had a permanent address (these accounted for $90 \%$ of all foreign farm workers). New workers often took up their jobs illegally. Illegal emigration reached about 50,000 people on an annual basis. In 1927-1932 illegal emigration (exceeding the quotas) was also present, but its scale was lower. After Germany closed its borders in 1933, all emigration became illegal. ${ }^{73}$ Seasonal emigration to work in the Baltic states also occurred, in particular to Latvia. This grew in the mid 1930s, and in 1936-1938 amounted to 18,000 to 22,000 people a year. ${ }^{74}$

${ }^{72}$ Maty Rocznik Statystyczny 1939, 53.

${ }^{73}$ Anna Poniatowska, Polskie wychodźstwo, 61-64.

${ }^{74}$ Maty Rocznik Statystyczny 1939, 52; for more information, see Ryszard Fyda, "Emigracja polska w Estonii w latach 1918-1939," Nasza Przeszłość. Studia z Dziejów Kościoła i Kultury Katolickiej w Polsce 1994, vol. 81, 220-226. 


\section{Conclusions}

Emigration on economic grounds became permanently incorporated in the social reality of Polish territories from the 1870s. Previously, its rate was low, and it occurred mostly in the Polish provinces under Prussian rule. Rapid growth was observed in the last decade of the 19th century and continued until the outbreak of World War I, when the rate of emigration decreased. When the Polish state was formed, emigration pressure did not decrease; however, the policies of immigration countries changed, which had a major effect on reducing the rate of emigration. The crisis in the 1930s brought a deep economic depression. The Polish government's policy, which encouraged emigration, could not change much. However, it must be emphasized that the organizational and institutional care of emigrants improved.

According to available estimates, during the 40 years before the First World War, about 3.5 million people emigrated from the territory of Poland, and during the 20 years between the World Wars it was about 1.5 million people. The above-mentioned data are not inclusive of re-emigrants, so the "loss" of population caused by emigration was lower than reported. It is estimated that before 1914, emigration accounted for nearly $30 \%$ of population growth from births, while in the interwar period it was $10 \%$.

The above data are not inclusive of seasonal emigration, mainly to Germany, the rate of which was subject to strong fluctuations. As regards the scale, at the turn of the 19th century it could reach 300,000 a year in connection to the fact that some workers did not return home in winter. According to some estimates, up to 600,000 people from the whole territory of Poland were living in Germany. In the interwar period the numbers fell significantly. According to official data, it was more than 80,000 people a year in the second half of the 1920s. The number of illegal emigrants is not known (it might have been tens of thousands of people).

In the interwar period, the directions of emigration changed markedly; in the 19th century two destinations were categorically predominant: the US and Germany (the first was chosen by settlement-oriented emigrants and the second by seasonal emigrants, but to some extent, also by settlement-oriented emigrants). In the interwar period, France was the predominant destination for permanent emigration. Germany was still the number one destination for seasonal emigrants.

As far as the distribution of emigrants according to the regions of Poland is concerned, the situation was as follows. Permanent emigration in 1870-1914, both in relative and absolute terms, mostly referred to the Polish territories incorporated in the German state, then to Galicia being a part of the Dual Monarchy (Austria-Hungary), and to a lesser extent to the Kingdom of Poland and eastern regions under Russian rule. The "loss" of population throughout the territory of Poland 
due to emigration was estimated at $11.8 \%$ of the population in 1912 ; in the western province it was $30 \%$ of the population, in the southern province, $13 \%$, the central, $6 \%$, and the eastern, $10 \%$. In the interwar period, the largest "loss" of population in relative and absolute numbers was recorded in the south-eastern voivodeships, followed by the Łódź, Poznań and Kielce voivodeships.

The territorial distribution of seasonal emigration was similar in both the periods analyzed. Its scale was determined by geographical location in relation to Germany: in the 19th century, the largest number of workers migrating in search of employment was recorded in the borderland regions. In the interwar period, these were the Łódź, Poznań and Kielce voivodeships. Large seasonal emigration from the Vilnius region to the Baltic states, including to Latvia, was quite a new phenomenon.

Estimating the rate of emigration in the 19th century is difficult with regard to the fact that the territory of Poland was a part of occupant states; hence, certain movements of people within the limits of the specific state is not formally considered to be emigration to a foreign country. Their scale is difficult to estimate. This paper contains approximate estimates.

\section{Bibliography}

\section{Source}

Annual Report of the Commissioner General of Immigration to the Secretary of Labor for the fiscal year ended 30 June 1891/92-1901/02, US Department of Labor, Washington 1892-1902.

Annual Report of the Commissioner General of Immigration to the Secretary of Labor for the fiscal year ended 30 June 1907, US Department of Labor, Washington 1907. Annual Report of the Commissioner General of Immigration to the Secretary of Labor for the fiscal year ended 30 June 1914, US Department of Labor, Washington 1915. Annual Report of the Commissioner General of Immigration to the Secretary of Labor for the fiscal year ended 30 June 1922, US Department of Labor, Washington 1922. Maty Rocznik Statystyczny 1939. Warszawa: GUS, 1939.

Rocznik Statystyki Rzeczypospolitej Polskiej of 1923. Warszawa: GUS, 1924.

Rocznik Statystyki Rzeczypospolitej Polskiej of 1925/1926. Warszawa: GUS, 1926.

Rocznik Statystyki Rzeczypospolitej Polskiej of 1927. Warszawa: GUS, 1927.

Rocznik Statystyki Rzeczypospolitej Polskiej of 1928. Warszawa: GUS, 1928.

Rocznik Statystyki Rzeczypospolitej Polskiej of 1929. Warszawa: GUS, 1929.

Rocznik Statystyki Rzeczypospolitej Polskiej of 1930. Warszawa: GUS, 1930.

"Statistique de l'émigration temporaire des ouvriers de 1900 à 1903 ses causes et son influence sur l'aisance de la population rurale de la région," Travaux du Comité Statistique à Varsovie 1902/03, no. XIX, 19. 
Statystyka Pracy 1932, no. 1, 102-104.

Statystyka Pracy 1933, no. 1, 45.

Statystyka Pracy 1934, no. 1, 38.

Statystyka Pracy 1935, no. 1, 60-62.

Statystyka Pracy 1936, no. 1, 53.

Statystyka Pracy 1937, no. 1, 68.

Statystyka Pracy 1938, no. 1, 25.

\section{References}

Avery H., Donald, and Jan K. Fedorowicz. Les Polonais au Canada. Ottawa: Société Historique du Canada, 1982.

Bobińska, Celina, ed. Mechanizmy polskich migracji zarobkowych. Warszawa: Książka i Wiedza, 1976.

Brożek, Andrzej. "Polityka imigracyjna w państwach docelowych emigracji polskiej (1850-1939)." In Emigracja z ziem polskich w czasach nowożytnych i najnowszych (XVIII-XX w.), edited by Andrzej Pilch. Warszawa: PWN, 1984.

Brożek, Andrzej. "Ruchy migracyjne z ziem polskich pod panowaniem pruskim w latach 1850-1918.” In Polonia amerykańska. Przeszłość i współczesność, edited by Hieronim Kubiak, Eugeniusz Kusielewicz, and Tadeusz Gromada. Kraków-Wrocław: Zakład Narodowy im. Ossolińskich, 1988.

Brożek, Andrzej. Polonia amerykańska 1854-1939. Warszawa: Interpress, 1977.

Caro, Leopold, and Karol English. Emigracja i polityka emigracyjna ze szczególnem uwzględnieniem stosunków polskich. Poznań: Drukarnia i Księgarnia Św. Wojciecha, 1914.

Derengowski, Jan. "Ruch migracyjny pomiędzy Polską a Stanami Zjednoczonymi Ameryki Północnej.” Statystyka Pracy 1927, no. 1, 41.

Drozdowski Marek M., ed. Problemy dziejów Polonii. Warszawa: PWN, 1979.

Dzieciuchowicz, Jerzy. „Polonia francuska - ewolucja struktury przestrzennej i demograficzno-społecznej." Acta Universitatis Lodziensis. Folia Geographica SocioOeconomica 2000, no. 3, 34.

Fawcett, James T. "Networks, Linkages, and Migration Systems." International Migration Review 1989, no. 23.

Fogelson, Samuel. "Robotnicy polscy we Francji w 1927 roku.” Statystyka Pracy 1930, no. 4,400 .

____ . "Rola wędrówek w rozwoju demograficznym Polski." Ekonomista 1937, vol. 1.

Fyda, Ryszard. "Emigracja polska w Estonii w latach 1918-1939." Nasza Przeszłość. Studia z Dziejów Kościoła i Kultury Katolickiej w Polsce 1994, vol. 81, 220-226.

Galos, Adam, and Kazimierz Wajda. "Migrations in the Polish Western territories annexed by Prussia (1815-1914)." In Employment-seeking Emigrations of the Poles World-Wide: XIX and XX C, edited by Celina Bobińska and Andrzej Pilch. Zeszyty 
Naukowe Uniwersytetu Jagiellońskiego, Prace Polonijne, no. 1, Kraków: PWN-UJ, 1975.

Gawryszewski, Andrzej. "Przestrzenna ruchliwość ludności Polski. Bibliografia (lata 1896-1990).” Dokumentacja Geograficzna 1997, no. 7, 152.

Groniowski, Krzysztof. “Świadomość chłopskiej emigracji w Stanach Zjednoczonych do roku 1918," Acta Universitatis Lodziensis. Folia Historica 1992, no. 45, 157.

___ Polska emigracja zarobkowa w Brazylii 1871-1914. Wrocław: Zakład Narodowy im. Ossolińskich, 1972.

Janowska, Halina. Emigracja zarobkowa z Polski 1918-1939. Warszawa: PWN, 1981.

. Polska emigracja zarobkowa we Francji, 1919-1939. Warszawa: Książka i Wiedza, 1964.

Jarzyna, Adam. Polityka emigracyjna. Lwów: Skład „Dom Książki Polskiej,” 1933.

Jezierski, Andrzej, and Andrzej Wyczański, eds. Historia Polski w liczbach, vol. 1, Państwo. Społeczeństwo. Warszawa: GUS, 2003.

Kołodziej, Edward. Wychodźstwo zarobkowe z Polski 1918-1939. Studia nad polityka emigracyjna II Rzeczypospolitej. Warszawa: Książka i Wiedza, 1982.

Kowalski, Grzegorz M. "Prawna regulacja wychodźstwa w Królestwie Polskim w latach 1815-1914.” Czasopismo Prawno-Historyczne 2003, no. 2, 237-238.

Kraszewski, Piotr. "Polsko-francuska konwencja emigracyjna z 3 września 1919 roku." Studia Polonijne 1972, no. 2, 103-104.

____ "Problem sezonowego wychodźstwa polskich robotników rolnych do Niemiec w latach 1919-1932.” Przegląd Zachodni 1985, no. 4, 26.

___ Polska emigracja zarobkowa w latach 1870-1939. Praktyka i refleksja. Poznań: Zakład Badań Narodowościowych PAN, 1995.

Kubiak, Hieronim, Eugeniusz Kusielewicz, and Tadeusz Gromada, eds. Polonia amerykańska. Przeszłość i współczesność. Kraków-Wrocław: Zakład Narodowy im. Ossolińskich, 1988.

Kula, Marcin. “Ameryka bliska i daleka.” In Emigracja, Polonia, Ameryka Lacińska: procesy emigracji i osadnictwa Polaków w Ameryce Lacińskiej i ich odzwierciedlenie $w$ świadomości społecznej, edited by Tadeusz Paleczny. Warszawa: Centrum Studiów Latynoamerykańskich. Uniwersytet Warszawski-CESLA, 1996.

Łazor, Jerzy. "Polityka migracyjna Drugiej Rzeczypospolitej - próba syntezy." In Od kwestii robotniczej do nowoczesnej kwestii socjalnej. Studia z polskiej polityki społecznej XXi XXI wieku. vol. III, edited by Paweł Grata. Rzeszów: Wydawnictwo Uniwersytetu Rzeszowskiego, 2015.

Łuczak, Czesław. Od Bismarcka do Hitlera. Polsko-niemieckie stosunki gospodarcze. Poznań: Wydawnictwo Poznańskie, 1988.

Łukawski, Zygmunt. Ludność polska w Rosji 1863-1914. Wrocław: Zakład Narodowy im. Ossolińskich, 1978.

Massey, Douglas. "Social Structure, Household Strategies, and the Cumulative Causation of Migration." Population Index 1990, vol. 56, no. 1.” 
Morawska, Ewa. "International migration: Its various mechanisms and different theories that try to explain it." Willy Brandt Series of Working Papers in International Migration and Ethnic Relations 2007, no. 1, 6-7.

___ "Labor migration of Poles in the Atlantic Economy, 1880-1914." Comparative Studies in Society and History 1989, no. 3.

Murzynowska Krystyna. "Polska emigracja zarobkowa w Niemczech w latach 18901918.” In Problemy dziejów Polonii, edited by Marek M. Drozdowski. Warszawa: PWN, 1979.

___ Polskie wychodźstwo zarobkowe w Zagłębiu Ruhry w latach 1880-1914. Wrocław: Zakład Narodowy im. Ossolińskich, 1979.

Niemyska, Maria. Remigracja z Francji $w$ dobie kryzysu: na tle wyników ankiety 1936 roku. Warszawa: Instytut Gospodarstwa Społecznego, 1939.

Okołowicz, Józef. Wychodźtwo i osadnictwo polskie przed wojna światowa. Warszawa: Urząd Emigracyjny, 1920.

Parczewski, Alfons J. "Emigracja z wschodnich prowincji Monarchii pruskiej.” Przegląd Emigracyjny 1892, no. 12, 123-125.

Pilch, Andrzej, ed. Emigracja z ziem polskich $w$ czasach nowożytnych i najnowszych (XVIII-XX w.). Warszawa: PWN, 1984.

. "Emigracja z ziem polskich do Stanów Zjednoczonych Ameryki od lat pięćdziesiątych XIX w. do r. 1918.” In Polonia amerykańska. Przeszłość $i$ współczesność, edited by Hieronim Kubiak, Eugeniusz Kusielewicz, and Tadeusz Gromada. Kraków-Wrocław: Zakład Narodowy im. Ossolińskich, 1988.

____ "Emigracja z ziem zaboru austriackiego (od połowy XIX w. do 1918 r.)." In Emigracja z ziem polskich w czasach nowożytnych i najnowszych (XVIII-XXw.), edited by Andrzej Pilch. Warszawa: PWN, 1984.

___ . "Trendy migracji zarobkowej ludności Galicji w XIX i XX w. (do 1918)." In Mechanizmy polskich migracji zarobkowych, edited by Celina Bobińska. Warszawa: Książka i Wiedza, 1976.

Poniatowska, Anna. Polskie wychodźstwo sezonowe na Pomorzu Zachodnim. Poznań: Wydawnictwo Poznańskie, 1971.

Praszałowicz, Dorota, Krzysztof A. Makowski, and Andrzej A. Zięba. Mechanizmy zamorskich migracji łańcuchowych w XIX wieku: Polacy, Niemcy, Żydzi, Rusini: zarys problemu. Kraków: Księgarnia Akademicka, 2004.

Puchalski, Piotr. "Polityka kolonialna międzywojennej Polski w świetle źródeł krajowych i zagranicznych: nowe spojrzenie (1918-1945).” Res Gestae. Czasopismo Historyczne 2018, no. 7, 68-83.

Skowron, Władysław. Emigracja sezonowa do Niemiec jako zagadnienie społeczne i gospodarcze. Warszawa: published by the author, 1931.

Spaleniak, Włodzimierz. "Prawno-polityczne aspekty emigracji sezonowej polskich robotników rolnych do Niemiec w latach 1919-1939.” Annales Universitatis Mariae Curie-Skłodowska 2002, vol. IX, 49-52. 
Stankiewicz, Zbigniew. "Procesy migracyjno-twórcze na ziemiach polskich w okresie zaborów. Migracje ekonomiczne.” In Mechanizmy polskich migracji zarobkowych, edited by Celina Bobińska. Warszawa: Książka i Wiedza, 1976.

Starczewski, Michał. “Z dziejów emigracji zarobkowej: agenci emigracyjni na ziemiach polskich przed 1914 r.” Przegląd Historyczny 2012, no. 1, 47-80.

Szawleski, Mieczysław. Wychodźtwo polskie w Stanach Zjednoczonych Ameryki. LwówWarszawa-Kraków: Zakład Narodowy im. Ossolińskich, 1924.

Szulc, Stefan. "Zagadnienia demograficzne Polski. Ruch naturalny ludności w latach 1895-1935. Dokładność rejestracji urodzeń i zgonów.” Statystyka Polski 1936, serie C, vol. 41, 8-10, 15.

Śladkowski, Wiesław. Emigracja polska we Francji 1871-1918. Lublin: Wydawnictwo Lubelskie, 1980.

Wajda, Kazimierz. Migracje ludności wiejskiej Pomorza Wschodniego w latach 18501914. Wrocław: Zakład Narodowy im. Ossolińskich, 1969.

Walaszek, Adam. Migracje Europejczyków 1650-1914. Kraków: Wydawnictwo Uniwersytetu Jagiellońskiego, 2007.

Zamorski, Krzysztof. “Ludność Galicji w latach 1857-1910.” In Informator statystyczny do dziejów społeczno-gospodarczych Galicji, edited by Helena Madurowicz-Urbańska. Kraków-Warszawa: UJ-PTS, 1989.

- Transformacja demograficzna w Galicji na tle przemian ludnościowych innych obszarów Europy Środkowej $w$ drugiej połowie XIX i na początku XX w. Kraków: UJ, 1991.

\section{Polish Emigration Abroad: Regional Structure and Streams of Emigration in the Years 1870-1914 and 1918-1939}

\section{Summary}

The paper aims at analyzing the processes of emigration from the territory of Poland from 1870-1938, determining their scale, regional structure and estimation of the net "loss" of population. The study primarily makes use of data from censuses as well as Polish and foreign emigration statistics. A comparative analysis was carried out at the level of provinces under foreign rule, groups of voivodeships and respective voivodeships in 1870-1938, estimating the intensity of emigration and net "loss" of population at the regional level. Emigration from the territory of Poland was a mass phenomenon at the end of the 19th century. Its characteristic feature was gainful emigration and the predominant destination was the US, followed by Germany. In the interwar period, the rate of emigration greatly decreased. The US and Germany became less popular destinations for emigrants, and emigration to France and Belgium gained in importance. In 1870-1914, permanent emigration in relative and absolute terms was the largest in the area under Prussian rule, then in Galicia, and to a lesser extent in the Kingdom of Poland and eastern 
regions. The "loss" of population throughout the territory of Poland due to emigration was estimated at $11.8 \%$ of the population in 1912; in the western district it was $30 \%$ of the population, in the southern district, $13 \%$, the central, $6 \%$, and the eastern, $10 \%$. In the period 1918-1938 the largest "loss" of population was recorded in the south-eastern voivodeships, followed by the Łódź, Poznań and Kielce voivodeships. In addition to permanent emigration, seasonal emigration (Germany, Latvia) was important from the economic and social points of view. Its rate was the highest at the end of the 19th century and in the first decade of the 20th century.

\section{Polska emigracja zagraniczna. Struktury regionalne i kierunki w latach 1870-1914 i 1918-1939}

\section{Streszczenie}

Przedmiotem artykułu jest analiza procesów emigracyjnych z ziem polskich w latach 1870-1938, określenie ich skali, struktury w układzie regionalnym oraz oszacowanie ubytku ludności netto. W badaniu wykorzystano przede wszystkim dane powszechnych spisów ludności oraz polskie i zagraniczne statystyki emigracyjne. Przeprowadzono analizę porównawczą na poziomie grup prowincji zaborczych, grup województw i województw w okresie 1870-1938, oszacowano natężenie emigracji i ubytek netto ludności na poziomie regionalnym. Emigracja z ziem polskich, jako zjawisko masowe w końcu XIX wieku, miała charakter zarobkowy, a dominującym jej kierunkiem były Stany Zjednoczone AP oraz Niemcy. W międzywojniu liczba emigrujących zmniejszyła się i spadła liczba wyjazdów do USA i Niemiec, zaś istotnego znaczenia nabrały wjazdy do Francji i Belgii. W okresie 1870-1914 emigracja „stała (osadnicza)” w ujęciu względnym i bezwzględnym w największym stopniu dotyczyła zaboru pruskiego, następnie Galicji, w mniejszej skali Królestwa Polskiego i Kresów Wschodnich. Ubytek ludności nią wywołany dla ogółu ziem polskich oszacowano na 11,8\% ludności z 1912 roku, dla dzielnicy zachodniej 30\%, południowej 13\%, centralnej 6\%, wschodniej 10\%. W okresie 1918-1938 największy ubytek ludności dotyczył województw południowo-wschodnich, następnie łódzkiego, poznańskiego i kieleckiego. Obok emigracji stałej bardzo ważna ekonomicznie i społecznie była emigracja sezonowa (Niemcy, Łotwa). Najwyższe rozmiary przybrała na przełomie XIX i XX wieku oraz w pierwszej dekadzie XX wieku. 
